\title{
The Roman Hinterland Project: Integrating Archaeological Field Surveys around Rome and Beyond
}

\author{
P.A.J. Attema ${ }^{1}$ (D) P. Carafa ${ }^{2}$ (D), W.M. Jongman ${ }^{3}$ (D) , C.J. Smith ${ }^{4}$ (D), \\ A.J. Bronkhorst ${ }^{1}$ (D), M.C. Capanna ${ }^{2}$ (D), T.C.A. De HaAs ${ }^{1,5}$ (D), \\ P.M. van Leusen ${ }^{1}$ (D), G.W. Tol ${ }^{6}$ (D), R.E. Witcher ${ }^{7}$ (D) AND N.A. Wouda ${ }^{8}$ (i) \\ ${ }^{1}$ Institute of Archaeology, University of Groningen, The Netherlands \\ ${ }^{2}$ Dipartimento di Scienze dell'Antichità, University of Rome La Sapienza, Italy \\ ${ }^{3}$ University of Groningen (retired), The Netherlands \\ ${ }^{4}$ School of Classics, University of St Andrews, Scotland, United Kingdom \\ ${ }^{5}$ Faculty of Archaeology. Leiden University, The Netherlands \\ ${ }^{6}$ School of Historical and Philosophical Studies, University of Melbourne, Australia \\ ${ }^{7}$ Department of Archaeology, Durham University, United Kingdom \\ ${ }^{8}$ Faculty of Economics and Business, University of Groningen, The Netherlands
}

This article presents the background to and prospects for a new initiative in archaeological field survey and database integration. The Roman Hinterland Project combines data from the Tiber Valley Project, Roman Suburbium Project, and the Pontine Region Project into a single database, which the authors believe to be one of the most complete repositories of data for the hinterland of a major ancient metropolis, covering nearly 2000 years of history. The logic of combining these databases in the context of studying the Roman landscape is explained and illustrated with analyses that show their capacity to contribute to major debates in Roman economy, demography, and the longue durée of the human condition in a globalizing world.

Keywords: settlement archaeology, data integration, comparative regional survey, urban-rural relations, rural demography, rural economy, suburbium of Rome

\section{INTRODUCTION}

The origins of Rome and its historical development have been a subject of archaeological study for centuries. For most of that time, the city has been conceptualized as an 'urban island', distinct from the surrounding territory, its rural hinterland often completely unacknowledged in accounts of the city's social and economic organization. Since the mid-twentieth century, however, archaeological surveys have mapped thousands of ancient sites and millions of artefacts in the region around the modern city. As a result, Rome and the surrounding territory now provide one of the most intensively studied combinations of a pre-industrial metropolis and its hinterland of any world region or period. Yet, issues of data inaccessibility, methodological incompatibility, and information management have limited the full realization of the potential value of this enormous archive of regional archaeological Archaeologists. This is an Open Access article, distributed under the terms of the Creative Commons AttributionNonCommercial-NoDerivatives licence (https://creativecommons.org/licenses/by-nc-nd/4.0/), which permits non-commercial re-use, distribution, and reproduction in any medium, provided the original work is unaltered and is properly cited. The written permission of Cambridge University Press must be obtained for commercial re-use or in order to create a derivative work.

doi:10.1017/eaa.2021.51 
data. In this article, we introduce a new initiative - the Roman Hinterland Project (RHP) - to build and populate an integrated and extensible database for the territory around ancient Rome. We present and situate the database within the context of archaeological 'big data', as well as Roman and Mediterranean landscape archaeology, and outline results to demonstrate its capacity to contribute to broader comparative studies of urbanism, economy, and demography.

The RHP is a consortium of members of three projects: the Tiber Valley Project (TVP), the Roman Suburbium Project (RSP), and the Pontine Region Project (PRP). Since 2017, it has worked on the formal integration of data from these long-term survey projects, the first data integration initiative of its kind in Mediterranean landscape archaeology. Its aims are two-fold:

1. ontological and technological: to make datasets generated with different methodologies and classifications comparable and to create and test a sustainable geospatial database infrastructure that allows complex querying (Van Leusen et al., in prep)

2. analytical and interpretive: to use consistently categorized site and artefact data to address fundamental questions on urban-rural relations, demography, and economic integration.

Through a series of workshops, the team initially explored the conceptual feasibility of the initiative in terms of the compatibility of site and artefact data. Thereafter, research funding from the Dutch Research Council and the British Academy has enabled the consortium to develop the methodology and infrastructure to integrate the three datasets. The resulting Roman Hinterland Project Database (RHPdb) now permits us to investigate research questions on the economic and demographic development of Rome and its hinterland, or suburbium, over the longue durée from protohistory to the early medieval period (Figure 1). An integral ambition of the initiative is to expand the RHPdb with additional regional survey datasets from Italy and potentially other Mediterranean regions (Attema et al., 2021), opening new avenues for comparative and aggregate analysis on even broader spatial scales.

Here, we reflect on our experience of bringing together three large and complex regional datasets and illustrate through examples the wider research value of this exercise. We start with a discussion of the opportunities and challenges of comparing, integrating, and generalizing survey data. Next, we provide an overview of the history of systematic survey archaeology in central Italy to contextualize the RHP initiative, and introduce the three constituent datasets. Finally, we show how the RHPdb can be used to address questions concerning production, consumption, connectivity, and demography in the suburbium of Rome over the longue durée.

\section{Survey Data: Comparison, INTEGRATION, AND GENERALIZATION}

The prospect of comparative survey work has enticed and challenged Mediterranean archaeologists for decades. Despite recognition of the potential value of aggregating survey data, whether from two neighbouring survey projects or across the wider Mediterranean, proponents have encountered significant methodological barriers (Alcock \& Cherry, 2004). Early examples of such work focused on Roman Greece (Alcock, 1993) and protohistoric and Roman Italy (Attema et al., 2010a). These studies demonstrate the potential of comparative survey to reveal larger 


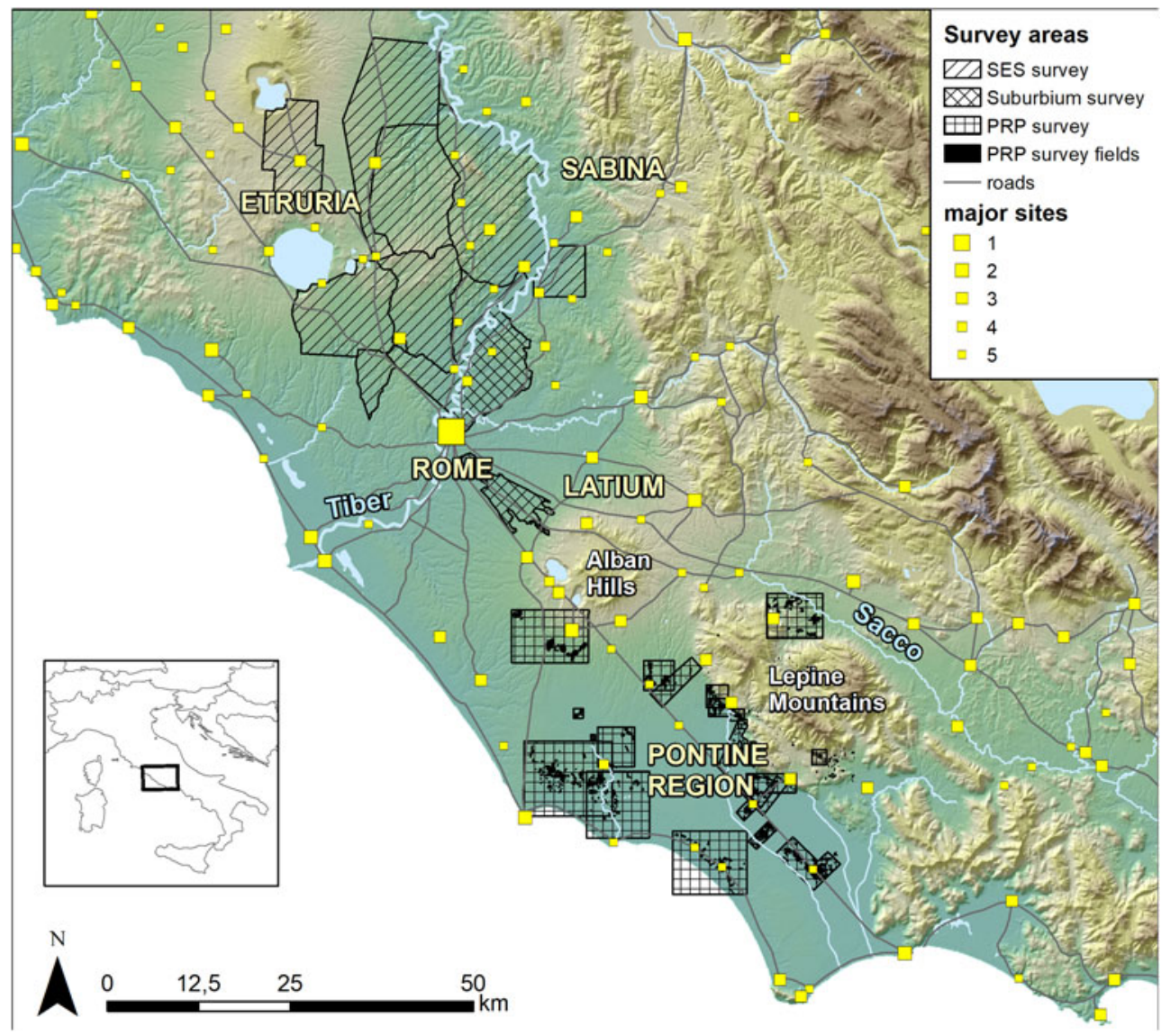

Figure 1. Rome, its suburbium, and areas covered by the South Etruria Survey/Tiber Valley Project, Roman Suburbium Project, and the Pontine Region Project. Major sites and (Roman) roads based on data from Talbert (2000).

spatio-temporal patterns than detectable by any single field survey project (Jongman, 2016). The examples cited, and others (e.g. Palmisano et al., 2017), however, rely on the comparison of simplified trends rather than the detailed integration of datasets, limiting the range and types of questions that can be addressed. The more formal integration of multiple datasets offers the potential to contribute to a much wider variety of research themes and to do so in more nuanced ways. Yet, despite the abundance and increasing accessibility of survey data, the complexity of data integration remains a challenge and progress has been slow (e.g. Leppard \& Knodell, 2020).
Archaeology, like many other disciplines, is confronted by a rich but unsystematic body of legacy data, combined with rapidly expanding quantities of digital and especially geospatial information (Witcher, 2008; Bevan, 2015; Cooper \& Green, 2016; 2017; McCoy, 2017). This archive presents significant conceptual and practical challenges in terms of uneven data quality, incompatible field methods, and issues around the objectivity of the description and meaningful interpretation of archaeological entities. These questions are particularly acute in relation to the documentation of survey data, where the size and composition of surface 
scatters may change from year to year, and the interpretation of site function and chronology may be reliant on the presence or absence of a few key types of material culture. Yet, the reward for integrating multiple survey datasets is not only a better understanding of, in our case, ancient Rome and the wider Mediterranean, but it also offers the opportunity to connect regional datasets to themes of global relevance (e.g. Kintigh et al., 2014). In this way, we aim to respond to the challenges posed by the 'big data' revolution in survey archaeology and to contribute to pressing research agendas in the humanities and social sciences. Researchers in these domains emphasize the significant contribution that archaeology can make through the supply of large datasets with deep chronologies and wide spatial coverage that can 'transform our evidence into reliable reconstructions of past social dynamics' (Smith et al., 2012: 7617) and stress that addressing fundamental questions on the reciprocal relationship between cultural process and environment requires 'both sophisticated modelling and large-scale synthetic research that are only now becoming possible' (Kintigh et al., 2014: 879).

Major research themes identified in these and other global and multidisciplinary research agendas resonate with our own aim of studying the longue durée of a metropolis and its hinterland within a globalized context. Our integrated database permits us to trace the rural population of Rome's immediate territory, from the origins of the city to the medieval period, and to illuminate the nexus between demography, economy, socio-political organization, and connectivity. It makes it possible to assess such issues as population size and demographic trends, economic organization and performance across time and space, living standards, the causal links between infrastructural investment and the intensification and abatement of agriculture, exchange within local, regional and inter-regional markets, and demonstrate how broader-scale integrated datasets can facilitate analysis of the wider Mediterranean economy (e.g. Witcher, 2005; Attema \& de Haas, 2011; Tol, 2017; de Haas, in press).

\section{The Microregional Datasets}

Regional survey archaeology as a complement to excavation has a long history in the Mediterranean, rooted in the work of early topographers who mapped ancient remains in the countryside (Cambi \& Terrenato, 1994). By the early twentieth century, it was already apparent that agricultural intensification, urban expansion, and infrastructure works (Ashby, 1927) were seriously damaging the archaeological landscape around Rome. This destruction accelerated during the decades after WWII, leading to the establishment of the South Etruria Survey, the first systematic, artefact-based survey within Rome's suburbium (Smith, 2018; Patterson et al., 2020). Since the 1970s, many other surveys, located within a wide radius of the city, have developed out of this long and evolving tradition, producing vast quantities of settlement and artefact data. Three of the largest long-term projects, located to the north, north-east, and south of Rome, are the TVP, RSP, and PRP respectively (Figure 1 ). Together they have documented 6687 sites and 546,484 artefacts, predominantly relating to the two millennia from the Late Bronze Age to the early medieval period.

Based at the British School at Rome, the TVP builds directly on the legacy of the pioneering South Etruria Survey (for a synthesis of the latter, see Potter, 1979). Between 1998 and 2002, a team of specialists completed a comprehensive re-study of the South Etruria Survey's paper 
archive and more than 75,000 sherds of pottery and other material originally collected between the 1950s and 1970s. In addition, the TVP integrated several other legacy datasets from the South Etruria Survey study area and extended the geographical coverage to the eastern, or 'Sabine', bank of the river Tiber to incorporate further datasets and to address new research questions about the regionality and connectivity of the middle valley. The resulting database of almost 5000 sites underpins a major new synthesis and digital archive and, for the first time, permits full and reliable use of the original South Etruria Survey data (Patterson et al., 2020).

Since 1993, the RSP of the University of Rome 'La Sapienza' has been collating legacy data and conducting new field surveys as part of a mapping initiative for the area immediately around modern Rome (Carandini et al., 2007). The project aims to reconstruct the ancient rural landscapes of Rome's suburbium through the systematic and intensive survey of three sample areas within the Municipality of Rome, sited along the consular roads: the Nomentana and Salaria, the Latina and Casilina, and along the Aurelia, an area of about $200 \mathrm{~km}^{2}$ (Capanna \& Carafa, 2019). In addition, all categories of evidence (e.g. archaeological features, textual sources, historical cartography) related to ancient sites and monuments in a zone around the city extending as far as the IX mile from the sixth-century BC city walls, have been classified and entered in the project's Archaeological Information System (AIS; Ippoliti, 2020).

The PRP began in 1987 as an extension of the University of Groningen's excavations of the ancient Latin city of Satricum, located south of Rome on the edge of the Pontine plain (Attema, 1993). The ongoing project aims to reconstruct the history of settlement and land use, from the Bronze Age to the Middle Ages, across the wider Pontine region comprising the Astura valley, the slopes and uplands of the Monti Lepini, the Pontine plain, and the coastal strip between Monte Circeo and Anzio (Attema et al., 2010b; Tol, 2012). Recently, the data gathered over the past thirty years by the various PRP surveys have been brought together in a single database that currently holds information on approximately 800 sites, $40-\mathrm{km}^{2}$ of off-site data, and 300,000 artefacts, of which some 25,000 are considered chronologically diagnostic (de Haas \& Tol, in prep).

\section{The Roman Hinterland Project Database}

By 2015, the TVP, RSP, and PRP had all reached critical points in their development. Much of the fieldwork and analysis of the material had been completed, but the need to think more deeply about the methodological diversity of their constituent datasets, the long-term sustainability of electronic databases, and how to connect these large datasets to new broader-scale research questions became obvious. This conjuncture of shared challenges brought the three projects into a dialogue leading to the initiative described here. Integrating data demands a critical attitude towards data quality and a consensus on data classification (de Haas \& Van Leusen, 2020). In the context of the RHP, each of the three projects has had to reconsider its own database architecture and resolve, or at least define, areas of uncertainty before the data could be integrated into the RHPdb. In the process, each database has been significantly improved. In this way, preparation for data integration is not only a prerequisite for ensuring the integrity and compatibility of the data, but also a valuable process 


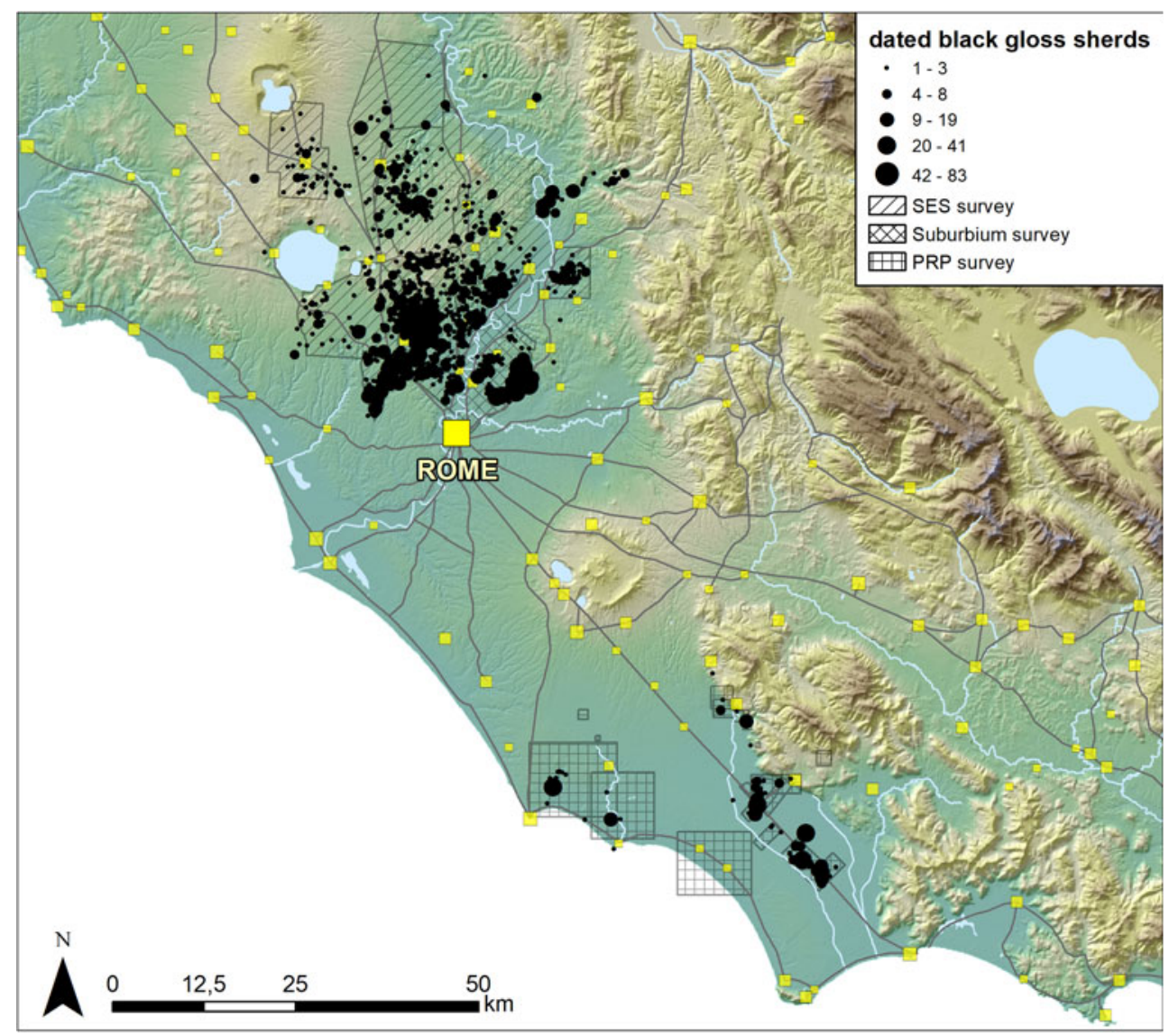

Figure 2. Distribution of typologically dated black gloss pottery sherds in the RHP database.

for understanding and improving the individual datasets in their own right (Witcher, 2008).

To date, work on the RHPdb structure has focused on the integration of data from sites and diagnostic ceramic material; other parts of the database still under development include more complex classes of diagnostic material, for example glass and metalwork, as well as non-diagnostic artefact data, such as tile, and survey sampling strategies. At the heart of the successful integration of data in the RHPdb is a strict policy of intensive data screening, or 'quality assurance'. To this end, the team has developed a protocol, which, in due course, will also facilitate the incorporation of further datasets (Van Leusen et al., in prep). Based on standardized typologies and robust quantification, we can now trace the spatial and diachronic spread of the material documented by generations of field surveys around the city of Rome. Figure 2, for example, shows the results of a query to extract and map the distribution of all diagnostic sherds (i.e. typologically datable sherds) of Republican-period black gloss ware. Figure 3 shows the results of a similar query for diagnostic amphora sherds collected by the three separate projects. Such distributions maps, plotting material culture ranging from general functional classes to highly diagnostic individual 


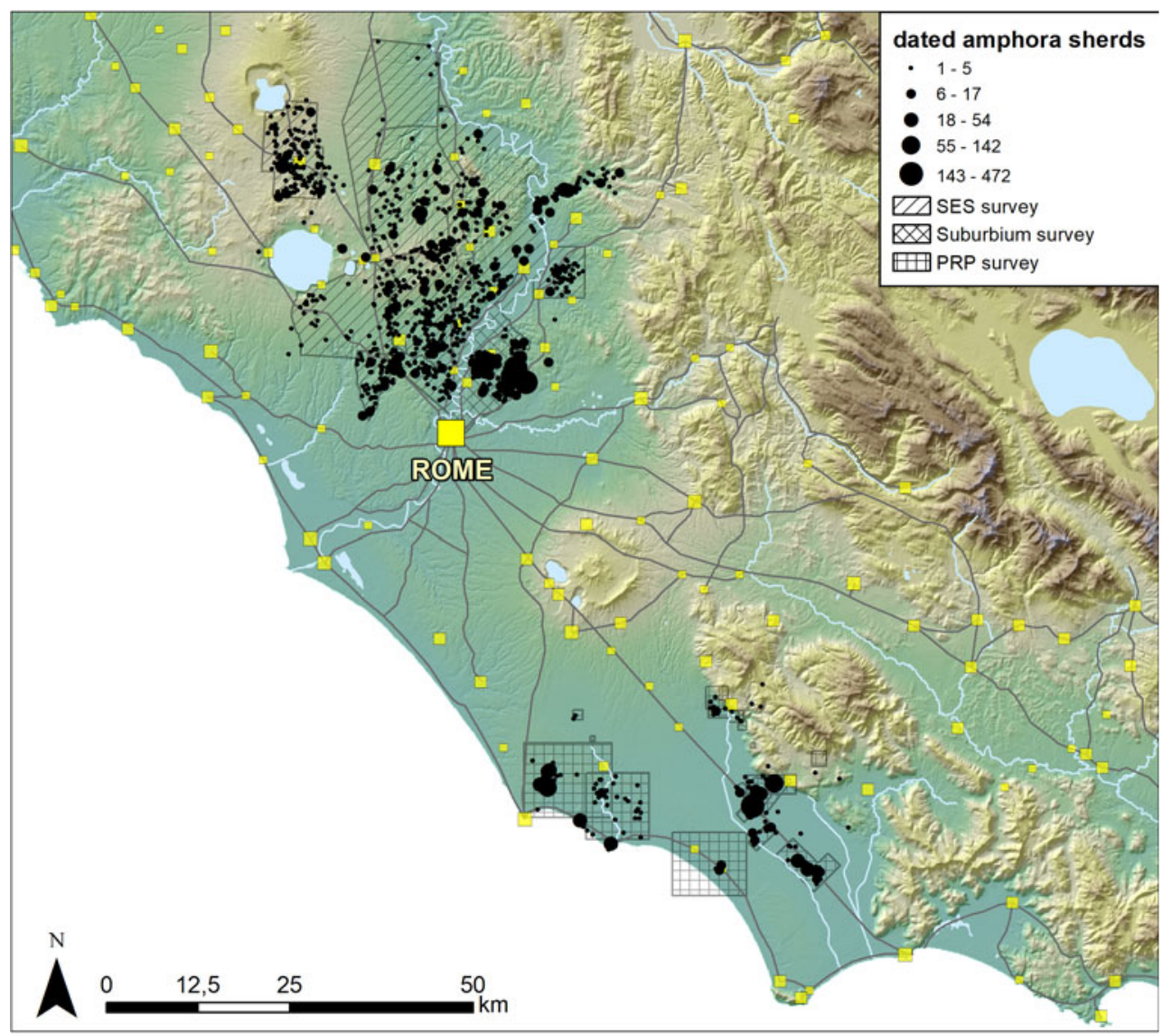

Figure 3. Distribution of typologically dated amphora sherds in the RHP database.

artefact types (e.g. Tol, 2012, 2017), underpin the analyses of economic integration, performance, and prosperity, as well as the exploration of the local and regional cultural preferences and diversities now coming more fully into focus via dedicated pottery studies (e.g. Roth, 2007).

In the next section, we present results drawn from the RHPdb to illustrate the growing integration of local and regional economies in the hinterland of Rome. The examples are framed temporally in relation to long-term developments in settlement and socio-political organization from protohistory to the early medieval period, and spatially within the context of shifting Mediterranean markets.

\section{The longue DURÉE OF THE RoMAN HiNTERLAND}

Through the course of the first millennium BC, Rome developed from a protourban polity into a metropolis at the centre of a 'global' empire. By the start of the first century AD, the Roman world had reached exceptional levels of cultural connectivity and economic exchange, representing one of the most important premodern 'globalizations' (Hodos, 2017). Because of the long fascination with, and study of, the city of Rome (Terrenato, 2019), this process of social, political, and economic expansion is usually narrated from an urban perspective (e.g. Hopkins, 
2000; but see Morley, 1996). Like all preindustrial societies, ancient Rome was nevertheless a fundamentally agrarian society. It is therefore essential to complement urban-centric interpretations with the abundant evidence from the city's hinterland in order to document and analyse socio-economic and demographic processes at a regional scale. To do so, we must not only aggregate and integrate the many available datasets, but also extend the chronological coverage back to encompass the protohistoric context out of which the city of Rome emerged.

\section{Protohistory (Bronze Age to Archaic Period)}

During the late second and early first millennia $\mathrm{BC}$, significant demographic, social, and economic developments led to state formation and the emergence of large urban settlements in central Italy. The nature of the urbanization that developed across the region from c. $900 \mathrm{BC}$ onwards is of particular importance for understanding the origins of Rome. It was characterized by the abandonment of small hilltop centres and the simultaneous establishment of fewer, larger sites, often on extensive plateaux (Pacciarelli, 2000; Fulminante, 2014). Field surveys have been used to map the extent and organization of these new urban sites (e.g. Veii; Cascino et al., 2012) and the degree, rate, and nature of rural infill in the territories around them. The emergence of dispersed rural settlement directly informs our analyses of political territories and of economic growth and integration. Survey data have already been used to challenge text-based narratives of Roman and medieval economies in this region (e.g. Moreland, 2010); the aggregation of data for the protohistoric period provides the basis for a similar revision of our understanding of pre-Roman settlement and economy. It also defines the socio-economic framework into which the polity of Rome expanded in the mid-first millennium BC.

\section{Republican Period}

If the study of protohistory is sometimes considered challenging because it lacks ancient texts, understanding the historical periods can be complicated by the biases and uncritical use of such literary sources (Terrenato, 2019). Earlier studies of the later second century BC, for example, privileged written accounts, using them to interpret survey data in terms of the displacement of peasants and the depopulation of rural landscapes (e.g. Hopkins, 1978). More recent work, drawing on larger datasets and adopting a more critical stance towards such texts, points to the persistence of small farmers and greater levels of economic activity (Launaro, 2011; Jongman, 2003). Crucially, whereas ancient texts rarely address rural matters and tend to generalize, survey data documents directly the complexity and diversity of local landscapes.

While the rural settlement history emerging from the RSP demonstrates an uninterrupted trend of Roman-period growth followed by a gradual decline in Late Antiquity, landscapes more distant from Rome in the Pontine region and in the remoter parts of the Tiber Valley reveal more variable trends, depending on local environment, urban infrastructure, connectivity, and market integration (de Haas, 2017). In general, however, the region around Rome had experienced significant demographic growth by the late Republican period. This may be partly explained by the incorporation of the territory's agrarian economy into the much larger and highly urbanized economic and political system stimulated by the growth 

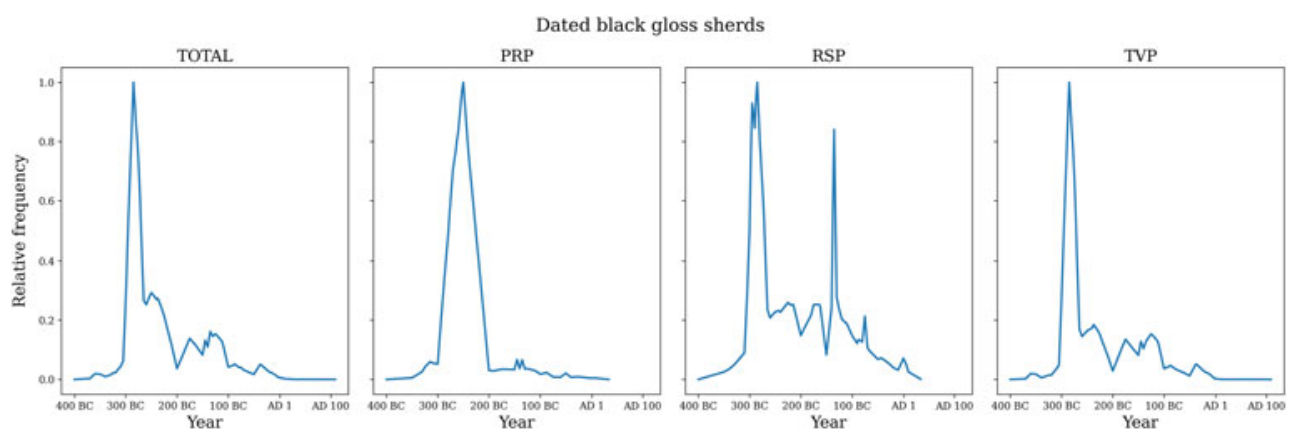

Figure 4. Relative frequencies of dated black gloss pottery sherds, with maximum frequency in each subfigure rescaled to 1 (TVP $n=2125 ; R S P n=165 ;$ PRP $n=402$ ).

of Rome and its Mediterranean empire (Hanson, 2016; Jongman, 2016), which led to greater availability and consumption of manufactured goods.

\section{Black Gloss Pottery as a Proxy for Prosperity and Cultural Preferences}

Here we use diachronic trends in the regional consumption of black gloss pottery to assess shifts in economic activity including production, exchange, and consumption. We also evaluate differences between the three project areas, or microregions, in order to explore possible divergences in their economic trajectories and cultural preferences. Figure 4 shows the relative frequencies over time of 2692 typologically dated sherds of black gloss pottery. The overall trend (left-hand graph) indicates relatively high levels of black gloss consumption in the early third century $\mathrm{BC}$, with a rapid decline in the mid-third century, followed by a more gradual decline through to the late first century BC. Examining the constituent datasets separately reveals that all three microregions peak in the early third century, indicating a moment of shared social, cultural, and economic activity. This peak is followed by regional variation in the subsequent centuries: very low levels of consumption in the Pontine region after 200 BC, relatively higher levels of consumption in the Tiber Valley and, especially, in the Roman suburbium. Broadly speaking, although the consumption of black gloss pottery universally declined during the final two centuries BC, this reduction was greater with distance from Rome, perhaps suggesting that these areas were less able to engage with the city's growing economy.

It is important to emphasize that these regional differences were not easily discernible before the RHP integrated the individual project databases. This is because earlier comparative attempts focused on sites rather than material culture and because the data screening and detailed mapping of the various projects' ceramic typologies undertaken by the RHP creates greater confidence in identifying emergent trends. It is therefore also possible to scrutinize these trends in greater detail. For example, focusing on the notable third-century BC peak, we find that it is composed of different types of black gloss in each of the microregions (Table 1). Hence, while Morel type 2783 and 2784 bowls (and various subtypes) were widely consumed across Rome's hinterland, other black gloss forms had more localized distributions. A case in point is the Morel 2538 cup. This shape was 
Table 1. Black gloss pottery types in the PRP, RSP, and TVP microregions (top five most abundant types only).

\begin{tabular}{lrlrlr}
\hline Pontine Region & \multicolumn{2}{c}{ Rome Suburbium } & \multicolumn{2}{c}{ Tiber Valley } \\
\hline Morel 2783/84 & 292 & Morel 2783/84 & 25 & Morel 2783/84 & 279 \\
Morel 2538 & 22 & Morel 2789 & 5 & Morel 2775c & 249 \\
Morel 1110-20 & 6 & Morel 2585b1 & 2 & Morel 321c4 & 87 \\
Morel 1111 & 4 & Morel 3511c1 & 2 & Morel 2538 & 67 \\
GPS Phase 3 & 4 & Morel 2775c & 2 & Petites estampilles & 65 \\
\hline
\end{tabular}

relatively common in the PRP and TVP microregions, but only two specimens have been identified within the RSP microregion. Production sites for Morel 2538 cups are suggested at Veii, Rome, and around Ostia (Olcese et al., 2010; Cascino et al., 2012: 260); it therefore appears that the kiln sites servicing the RSP microregion chose not to include this shape in their offer.

\section{Early and Mid-Imperial Period}

A central focus of current research on the Roman economy and society concerns economic performance: how successful was Rome in meeting the needs and wants of the expanding empire's population, and how were goods distributed among different social groups ( Scheidel \& Friesen, 2009; Jongman, 2014; Jongman et al., 2019)? How do standards of living during the late Republican and early imperial periods compare with those of other preindustrial societies, and how far and for how long, if at all, did these standards of living rise above subsistence level (Allen et al., 2005; Clark, 2008)? What was the social distribution of the benefits of economic growth-a small elite or larger parts of the population? And how does the economic performance of the early and mid-empire relate to the scale and organization of economic activity during earlier and subsequent periods? Amphorae constitute an important category of pottery for the examination of these questions. Below we assess the integration of regional and microregional economies into panMediterranean markets using the diachronic frequency and provenance of amphora sherds from North Africa, central Tyrrhenian Italy (= regional Italy), northern, Adriatic, and southern Italy (= non-regional Italy), the Iberian Peninsula, Gaul, the Aegean, and the Eastern Mediterranean.

\section{Amphorae as a Proxy for pan-Mediterranean Market INTEGRATION}

Amphorae are routinely used to reconstruct the scale and organization of the Roman economy. The material used generally comes from the excavation of urban sites and shipwrecks. Bearing in mind that the majority of the population of the Roman Mediterranean lived in rural landscapes, survey data offer the potential to assess consumption patterns at the regional scale. By integrating amphora data from the three microregions within the RHPdb, we can plot their geographical and temporal distributions, which we use to address questions about interregional and pan-Mediterranean economic connectivity. In doing so, we assume that the contents of these amphorae were consumed at the sites from which the sherds were recovered (e.g. they were not consumed on urban sites and the amphorae 


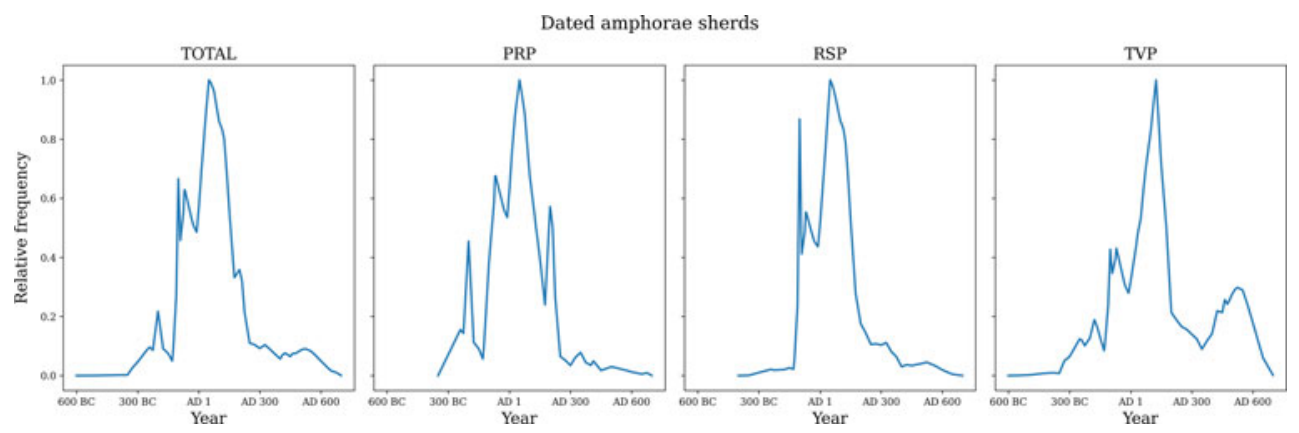

Figure 5. Relative frequencies of dated amphora sherds per year, with maximum frequency in each subfigure rescaled to 1 (TVP $n=725 ; R S P n=1238 ; P R P n=1428$ ).

recycled as building materials on rural sites); we also make use of a 'triangular' weighted model that assumes that use and deposition were more probable around the midpoint of the chronological production span of any particular amphora type (Willet, 2014).

Figure 5, based on a total of 3391 amphora sherds, shows the changing consumption of imported wine, and to a much lesser extent of oil and fish sauce, in the Roman suburbium. The trend tracks the pattern of increased economic activity and long-distance exchange between $c$. $200 \mathrm{BC}$ and $\mathrm{AD} 200$ familiar from a number of other proxy datasets (e.g. Bowman \& Wilson, 2009; Jongman, 2014). Comparing the overall consumption trend to those derived from the three component datasets reveals notable variations. The small spike in the late third/early second century BC is caused by increased consumption especially south of Rome (and to a lesser extent in the TVP microregion); the area south of Rome was apparently more reliant on imported wine at this stage, whereas areas north of Rome depended more on locally produced wine (which was not supplied in heavy amphorae intended for maritime transport). The Tiber Valley shows much higher levels of amphora imports during Late Antiquity than documented in the other microregions, which could in part be a result of a better knowledge of late antique amphorae by the TVP, allowing recognition of a larger percentage of the material; however, we do not believe this fully explains the marked difference with the other microregions.

Figures 6 and 7 highlight more specific trends in amphora provenance over time. Figure 6 compares the overall frequencies of amphorae produced in central Tyrrhenian Italy (= regional Italy) to those produced elsewhere in Italy and beyond (= non-regional Italy); the trend of the latter tracks the former with a delay of around 75 years. From c. 200 BC, non-regional amphorae appear in the hinterland alongside regional products; after c. AD 150, non-regional amphorae dominate, with hardly any consumption of regional products. This suggests that demand for wine in the hinterland was initially met by production within the region (central Italy), but from c. 200 BC external suppliers entered the market. Initially demand exceeded supply, so both regional and nonregional producers could continue to expand supplies in the first half of the first century AD. Thereafter, growth came to an end but, while the regional supply collapsed in the second century $\mathrm{AD}$, non-regional producers sustained their supply for another 75 years, before a sharp reduction in the third century $\mathrm{AD}$-albeit a less 
Relative frequency of dated amphorae sherds by (non-)regional provenance

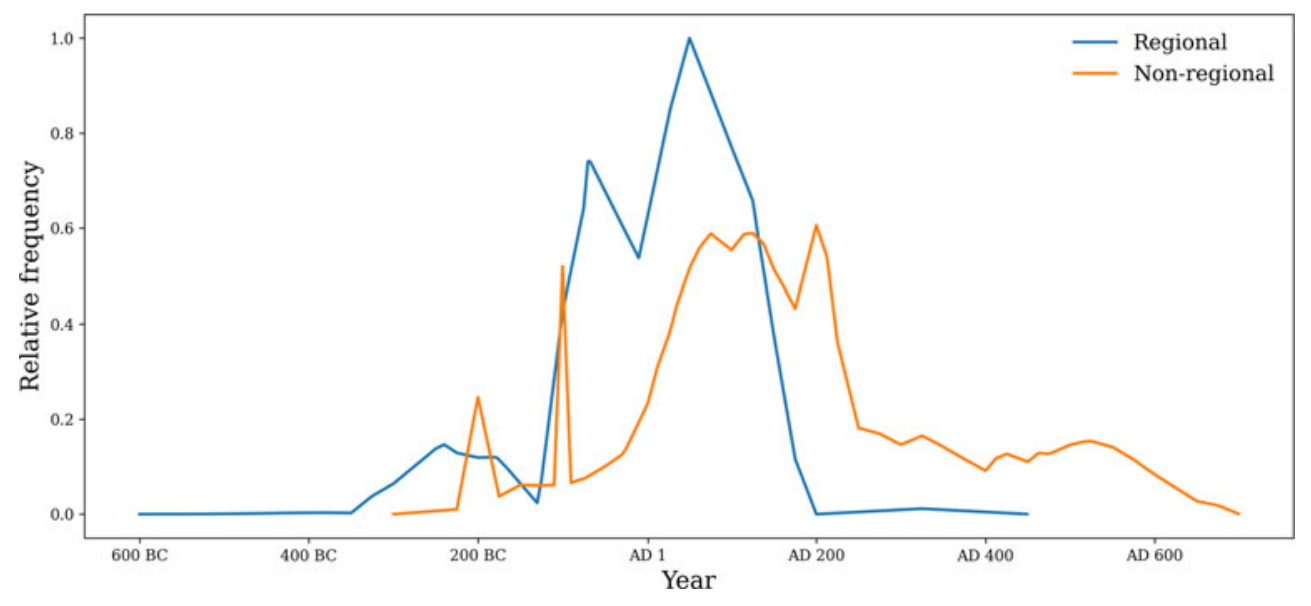

Figure 6. Relative frequencies of amphora sherds of regional (Central Italian) versus non-regional provenance deposited per year, with maximum frequency rescaled to 1.

dramatic decline than that of the regional producers-and with supplies continuing into Late Antiquity. Figure 7 shows the modelled numbers of amphora sherds deposited per year for each of the nonregional provenance groups; the left-hand column displays the aggregate chronological trend for each provenance group and the following three columns break down this trend by individual microregion. The graphs in the aggregate column demonstrate clear successive temporal shifts in the provenances of amphorae imported into the suburbium between $200 \mathrm{BC}$ and $\mathrm{AD} 500$. The sources of these imports move from North Africa to non-regional Italy, to Iberia and back to North Africa, before finally shifting to the Eastern Mediterranean. Between AD 1 and 250, amphorae were also supplied from Gaul and the Aegean. These trends document phases of shifting, predominantly regional integration, with a core period of particularly broad and intensive panMediterranean integration during the first two centuries AD (Woolf, 1992).

As with black gloss pottery, disaggregating the general trend for each amphora provenance group reveals notable variations between the three microregions. For example, Italian amphorae from beyond central Italy are almost absent from the PRP microregion; Eastern Mediterranean amphorae are almost exclusively restricted to the TVP microregion; and the supply of African amphorae shows two distinct peaks in the PRP microregion, which are absent in the other two areas. The supply of amphorae from Iberia and Gaul shows similar trends across all three datasets, whereas Aegean amphorae were consumed mostly in and around Rome itself. Here again, the examples of shifting provenance and quantities of amphorae imports presented demonstrate how combining survey data facilitates the reconstruction of global production and supply trends and brings insights into local consumption patterns.

\section{Late Antiquity and the Early Medieval Period}

The late imperial/late antique period in central Italy is characterized by a remarkable economic and demographic decline. 
Relative frequency of dated amphorae sherds by microregion
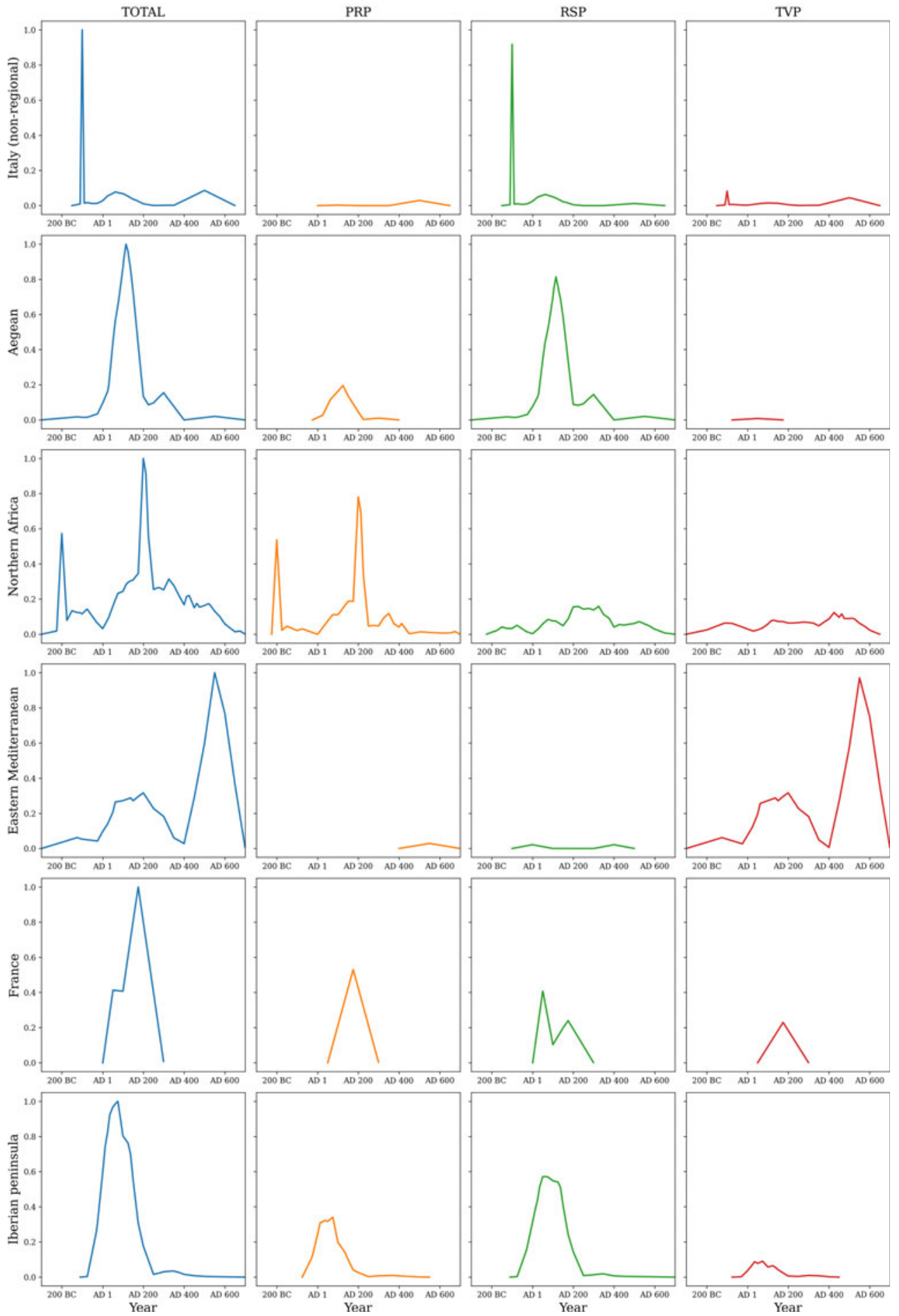

Figure 7. Relative frequencies of amphora sherds by microregion of amphora provenance. The graphs in each row (microregion) are rescaled to set the maximum frequency in the totals column of that row to 1 . 
It is, however, difficult to pinpoint the start of this downturn and to map in detail its spatial and chronological variability. In the area around Rome, these changes appear to have begun sometime between $\mathrm{AD} 100$ and 250 and, as suggested by the amphora analyses presented above, even within this relatively small region, there appears to have been some variation in the timing, pace, and scale of change. Various explanations for this disintegration and reduction in the complexity of the regional economy have been advanced, including the political and military crises of the third century $\mathrm{AD}$, the 'Antonine Plague' that ravaged the empire from the mid-160s, or a combination of these and other factors (e.g. Duncan-Jones, 2004; Ward-Perkins, 2005; Lo Cascio, 2012). While it is doubtful that landscape archaeology can, or should, attempt to address questions focused on specific historical events, work by all three individual projects to extract trends at the scale of the Braudelian conjoncture have added to our understanding of the transformation of Rome's suburbium during the late antique and early medieval periods (Capanna \& Carafa, 2019; Patterson et al., 2020; Satijn, 2020), an understanding that the planned integration of additional classes of pottery from these periods into the RHPdb will further enhance.

Our results provide an outline of how a regional perspective on the emergence and long-term development of Rome and its hinterland can be rewritten using multiple legacy datasets rigorously integrated to provide new and robust insights. The RHPdb now makes it possible to map with confidence the spatial and temporal distributions of settlements of all types and sizes, as well as multiple categories of artefact types, illuminating economic and demographic processes across two millennia. What remains is the critical task of defining the many and diverse connections -local, regional, and global-that linked and drove these processes. It was these connections, for example, that created the period of unprecedented cultural and economic integration during the early empire. Only by isolating and evaluating these considerations can we deconstruct and rewrite the standard text-based narratives of the 'rise and fall' of Rome.

\section{Conclusions}

Here, we have introduced a new collaborative project that seeks not simply to compare but also to integrate three major Mediterranean survey datasets that together provide expansive coverage of the immediate hinterland of one of the world's largest pre-industrial cities. By creating a systematic regional-scale dataset that incorporates areas to the north, north-east, and south of Rome, we aim to address questions of central importance for Roman archaeologists and ancient historians. Beyond that, we aim to bring the powerful combination of 'big data' and an iconic ancient metropolis and its hinterland to research questions of wider historical interest, as well as contemporary challenges.

To this end, we have presented examples showing how we can identify with some confidence similarities and differences in the spatial and temporal trends in three component datasets/microregions, and these results speak to questions of both economic and wider cultural significance. Analysis of Republican-period black gloss pottery demonstrates that the widespread mid-Republican peak in consumption is composed of a few locally made but regionally shared vessel types, plus many unique local types with limited distributions; beneath the overarching economic trend, we can now discern local differences and preferences. As for the amphora data, they suggest successive phases of economic 
integration, from regional, to panMediterranean and back to regional; within this broad trend, we can also track the emergence and disappearance of provincial supply regions as well as spatial variations in consumption patterns across the suburbium.

All three component projects have benefited from the profound methodological reflections on field survey of the last four decades and we have brought this experience to the process of designing the RHPdb. At the same time, consistent approaches to pottery chronology have matured across the region, making the ceramic identifications from each survey project increasingly comparable. Hence, despite the methodological impasse that has long held back the ambition to compare surveys across vast geographical areas, we are now capable of making real advances in the integration of the enormous archive of legacy survey data from this region.

Expanding the RHPdb with additional high-quality datasets from elsewhere in Italy and beyond is a priority and will make it possible for researchers to study urbanization and ruralization systematically across large parts of the ancient world, in effect Rome's Mediterranean hinterland. Our consortium is fostering a user community to expand the number of datasets and to extend its geographical coverage, in order to advance our experience of archaeological survey integration and serve as a training network for early-career landscape archaeologists. Trials of a protocol for the integration of additional highquality datasets are underway.

The integration of our constituent datasets allows us to address anew long-standing questions about ancient Rome. It coincides with an era in which topical questions of much broader geographical and chronological scope are being posed. The creation of a robust and systematic body of information makes it possible to conduct not simply a study of Rome and its suburbium but a structural analysis of a pre-industrial metropolis and its hinterland. While ancient Rome was extraordinary in its size, power, and influence, it was not unique. Indeed, though Roman archaeologists have sometimes considered the city to be sui generis, scholars of urban history regularly look to Rome as part of broad comparative studies. Where Rome does offer unique insight, however, is in the unparalleled quantity of survey work undertaken in the immediate territory of the city over the past 150 years. The RHPdb leverages the collective value of these legacy data-much greater than the sum of the parts- to lay the foundation for a new analysis of the ancient city from the perspective of its hinterland, making it possible to contribute to urban and economic studies more generally. How do mega-cities create and relate to their hinterlands? What is the relationship between urban and rural populations? Is the hinterland an extension of the city? What reserves of resilience and opportunity remain beyond and independent of the urban core? These questions have wide and current significance and matter not only to archaeologists but also to economists, urban historians, and others.

Today, we often hear that we live in an age of cities. By definition, therefore, we also live in an age of hinterlands. Turning our attention to the positive and negative impacts of an ancient city on its immediate territory, economic, ecological, social, and cultural, has broad contemporary as well as historical relevance, pertinent far beyond ancient Rome.

\section{ACKNOWLEDGEMENTS}

We thank the University of Groningen for a starting grant and the Dutch Research 
Council (NWO) for funding 'Integrating Field Surveys - Rome and Beyond' (grant IG. 2017-GW, file number IG.17.026, applicant University of Groningen, Attema, Jongman, Van Leusen) cofinanced by the British Academy/British School and the universities of Cologne, Durham, Melbourne, and La Sapienza, Rome. With the transfer of de Haas from Cologne to Leiden University, the latter university has replaced Cologne in the project. We also thank the Royal Netherlands Institute in Rome for hosting a series of workshops to develop the RHP database and related research frameworks.

\section{REFERENCES}

Alcock, S.E. 1993. Graecia Capta: The Landscapes of Roman Greece. Cambridge: Cambridge University Press.

Alcock, S.E. \& Cherry, J.F. eds. 2004. Sideby-Side Survey: Comparative Regional Studies in the Mediterranean World. Oxford: Oxbow.

Allen, R.C., Bengtsson, T. \& Dribe, M. eds. 2005. Living Standards in the Past: New Perspectives on Well-Being in Asia and Europe. Oxford: Oxford University Press.

Ashby, T. 1927. The Roman Campagna in Classical Times. London: Ernest Benn.

Attema, P.A.J. 1993. An Archaeological Survey in the Pontine Region: A Contribution to the Early Settlement History of South Lazio, 900-100 BC. Groningen: University of Groningen.

Attema, P.A.J. \& de Haas, T.C.A. 2011. Rural Settlement and Population Extrapolation: A Case Study from the Ager of Antium, Central Italy (350 BC-AD 400). In: A. Bowman \& A. Wilson, eds. Settlement, Urbanisation, and Population. Oxford: Oxford University Press, pp. 97-140.

Attema, P.A.J., Burgers, G-J.L.M. \& Van Leusen, P.M. 2010a. Regional Pathways to Complexity: Settlement and Land-Use Dynamics in Early Italy from the Bronze Age to the Republican Period. Amsterdam: Amsterdam University Press.

Attema, P.A.J., de Haas, T.C.A. \& Tol, G. W. 2010b. Between Satricum and Antium:
Settlement Dynamics in a Coastal Landscape in Latium Vetus. Leuven: Peeters.

Attema, P.A.J, de Haas, T.C.A., Seubers, J.F. \& Tol, G.W. 2021. Towards an Integrated Database for the Study of Long-Term Settlement Dynamics: Economic Performance and Demography in the Pontine Region and the Hinterland of Rome. In: P.A.J. Attema \& G. Schörner, eds. The Rural Foundations of the Roman Economy: New Approaches to Rome's Ancient Countryside from the Archaic to the Early Imperial Period. Cologne, Bonn: Heidelberg Propylaeum.

Bevan, A. 2015. The Data Deluge. Antiquity, 89: 1473-84.

Bowman, A. \& Wilson, A. 2009. Quantifying the Roman Economy: Integration, Growth, Decline? In: A. Bowman \& A. Wilson, eds. Quantifying the Roman Economy: Methods and Problems. Oxford: Oxford University Press, pp. 3-84.

Cambi, F. \& Terrenato, N. 1994. Introduzione all'archeologia dei paesaggi. Rome: Nuova Italia Scientifica.

Capanna, M.C. \& Carafa, P. 2019. I paesaggi rurali tra il suburbio di Roma e il Latium vetus. In: A.L. Fischetti \& P.A.J. Attema, eds. Alle pendici dei Colli Albani. dinamiche insediative e cultura materiale ai confini con Roma. Groningen: Barkhuis, pp. 15-28.

Carandini, A., Carafa, P. \& Capanna, M.C. 2007. Archeologia del suburbio di Roma per la ricostruzione dei paesaggi agrari antichi. Il progetto "Archeologia del suburbio di Roma per la ricostruzione dei paesaggi agrari antichi”. Impostazione e metodologia della ricerca. In: C. Cupitò, ed. Il suburbio di Roma antica. La topografia del suburbio tra la Salaria, l'Aniene, il Tevere e la c.d. Salaria Vetus. Rome: Bretschneider, pp. 13-25.

Cascino, R., Di Giuseppe, H. \& Patterson, H. eds. 2012. Veii. The Historical Topography of the Ancient City: A Restudy of John Ward Perkins's Survey. London: British School at Rome.

Clark, G. 2008. Farewell to Alms: A Brief Economic History of the World. Princeton: Princeton University Press.

Cooper, A. \& Green, C. 2016. Embracing the Complexities of 'Big Data' in Archaeology: The Case of the English Landscape and Identities Project. Journal of Archaeological Method and Theory, 23(1): 
271-304. https://doi.org/10.1007/s10816015-9240-4

Cooper, A. \& Green, C. 2017. Big Questions for Large, Complex Datasets: Approaching Time and Space Using Composite Object Assemblages. Internet Archaeology, 45. https://doi.org/10.11141/ ia. 45.1

de Haas, T.C.A. 2017. The Economic Geography of Roman Italy and its Implications for the Development and Integration of Rural Economies. In: T.C. A. de Haas \& G.W. Tol, eds. The Economic Integration of Roman Italy: Rural Communities in a Globalizing World. Leiden: Brill, pp. 51-82.

de Haas, T.C.A. in press. Urban, Rural and in Between: Long-Term Population Developments, Central Place Landscapes and Infrastructure in the Pontine Region, Central Italy. In: G.W. Tol \& T.C.A. de Haas, eds. Between Urban and Rural: Results and Data of the Minor Centres Project. Eelde: Barkhuis Publishing.

De Haas, T.C.A. \& Tol, G.W., in prep. The Analytical Potential of Intensive Field Survey Data: Developments in the Collection, Analysis and Interpretation of Surface Ceramics within the Pontine Region Project. In: A. Meens, M. Nazou \& W. van de Put, eds. Fields, Sherds and Scholars: Recording and Interpreting Survey Ceramics.

de Haas, T.C.A. \& Van Leusen, P.M. 2020. FAIR Survey: Improving Documentation and Archiving Practices in Archaeological Field Survey through CIDOC CRM. Fasti Online Documents \& Research, 12 [online] [accessed 5 July 2021]. Available at www.fastionline.org/docs/FOLDERsur-2020-12.pdf

Duncan-Jones, R.P. 2004. Economic Change and the Transition to Late Antiquity. In: S. Swain \& M. Edwards, eds. Approaching Late Antiquity: The Transformation from Early to Late Empire. Oxford: Oxford University Press, pp. 20-52.

Fulminante, F. 2014. The Urbanisation of Rome and Latium Vetus from the Bronze Age to the Archaic Era. Cambridge: Cambridge University Press.

Hanson, J.W. 2016. An Urban Geography of the Roman World, 100 BC. to AD. 300. Oxford: Archaeopress.
Hodos, T. ed. 2017. The Routledge Handbook of Globalization and Archaeology. London: Routledge.

Hopkins, K. 1978. Conquerors and Slaves. Cambridge: Cambridge University Press.

Hopkins, K. 2000. Rent, Taxes, Trade and the City of Rome. In: E. Lo Cascio, ed. Mercati permanenti e mercati periodici nel mondo romano. Bari: Edipuglia, pp. 25367.

Ippoliti, M. 2020. Tra il Tevere e la Via Appia. Caratteri e sviluppo di un paesaggio suburbano di Roma antica tra IX Secolo a.C. e VI Secolo d.C. Rome: Quasar.

Jongman, W.M. 2003. Slavery and the Growth of Rome. In: C. Edwards \& G. Woolf, eds. Rome the Cosmopolis. Cambridge: Cambridge University Press, pp. 100-22.

Jongman, W.M. 2014. Re-Constructing the Roman Economy. In: L. Neal \& J. Williamson, eds. The Cambridge History of Capitalism. Cambridge: Cambridge University Press, pp. 75-100.

Jongman, W.M. 2016. Italian Urbanization and Roman Economic Growth. In: L. Capogrossi Colognesi, E. Lo Cascio \& E. Tassi Scandone, eds. L'Italia dei Flavi. Rome: Bretschneider, pp. 105-17.

Jongman, W.M., Jacobs, J.P.A.M. \& Goldewijk, G.K. 2019. Health and Wealth in the Roman Empire. Economics and Human Biology, 34: 138-50.

Kintigh, K.W., Altschul, J.H., Beaudry, M.C., Drennan, R.D., Kinzig, A.P., Kohler, T.A. 2014. Grand Challenges for Archaeology. Proceedings of the National Academy of Sciences, 111: 879-80.

Launaro, A. 2011. Peasants and Slaves: The Rural Population of Roman Italy. Cambridge: Cambridge University Press.

Leppard, T.P. \& Knodell, A.R. 2020. Retrospect and Prospect in Regional Archaeology. In: A.R. Knodell \& T.P. Leppard, eds. Regional Approaches to Society and Complexity: Studies in Honour of John F. Cherry. Sheffield: Equinox, pp. 320-37.

Lo Cascio, E. ed. 2012. L'impatto della "Peste Antonina". Bari: Edipuglia.

McCoy, M.D. 2017. Geospatial Big Data and Archaeology: Prospects and Problems too Great to Ignore. Journal of Archaeological Science, 84: 74-94. 
Moreland, J. 2010. Archaeology, Theory and the Middle Ages: Understanding the Early Medieval Past. London: Duckworth.

Morley, N. 1996. Metropolis and Hinterland: The City of Rome and the Italian Economy, $200 B C-A D$ 200. Cambridge: Cambridge University Press.

Olcese, G., Capelli, C., Carconi, A., Ceccarelli, L., Giunta, S., Manzini, I, et al. 2010. Le ceramiche a vernice nera nel IV e III secolo a.C. dell'Ager Portuensis e di Ostia: notizie preliminari sulle ricerche archeologiche e archeometriche. Bollettino di Archeologia online, 1: 2010/Special volume B/B8/2. https:// bollettinodiarcheologiaonline.beniculturali. it/wp-content/uploads/2019/01/2_OLCESE_ e_altri.pdf

Pacciarelli, M. 2000. Dal villaggio alla città: la svolta protourbana del 1000 a.C. nell'Italia tirrenica. Firenze: All'Insegna del Giglio.

Palmisano, A., Bevan, A. \& Shennan, S. 2017. Comparing Archaeological Proxies for Long-Term Population Patterns: An Example from Central Italy. Journal of Archaeological Science, 87: 59-72. https:// doi.org/10.1016/j.jas.2017.10.001

Patterson, H., Witcher, R.E. \& Di Giuseppe, H. 2020. The Changing Landscapes of Rome's Northern Hinterland: The British School at Rome's Tiber Valley Project. Oxford: Archaeopress.

Potter, T.W. 1979. The Changing Landscape of South Etruria. London: Elek.

Roth, R. 2007. Styling Romanisation: Pottery and Society in Central Italy. Cambridge: Cambridge University Press.

Satijn, O.P.N. 2020. Campagna di Roma Olim Latium: A Historical Landscape Archaeology of Tyrrhenian Southern Lazio from Late Antiquity to Incastellamento ( $\mathrm{PhD}$ dissertation, University of Groningen). https://doi. org/10.33612/diss.125947886

Scheidel, W. \& Friesen, S. 2009. The Size of the Economy and the Distribution of Income in the Roman Empire. Journal of Roman Studies, 99: 61-91.

Smith, C.J. 2018. J.B. Ward-Perkins, the BSR and the Landscape Tradition in Post-War Italian Archaeology. Papers of the British School at Rome, 86: 271-92.

Smith, M.E., Feinman, G.M., Drennan, R.D., Earle, T. \& Morris, I. 2012. Archaeology as a Social Science. Proceedings of the National Academy of Sciences, 109: 7617-21.
Talbert, R. ed. 2000. The Barrington Atlas of the Greek and Roman World. Princeton: Princeton University Press.

Terrenato, N. 2019. The Early Roman Expansion into Italy. Elite Negotiation and Family Agendas. Cambridge: Cambridge University Press.

Tol, G.W. 2012. A Fragmented History: A Methodological and Artefactual Approach to the Study of Ancient Settlement in the Territories of Satricum and Antium. Groningen: Barkhuis.

Tol, G.W. 2017. From Surface Find to Consumption Trend: A Ceramic Perspective on the Economic History of the Pontine Region (Lazio, Central Italy) in the Roman Period. In: T.C.A. de Haas \& G.W. Tol, eds. The Economic Integration of Roman Italy: Rural Communities in a Globalizing World. Leiden: Brill, pp. 367-87.

Van Leusen, P.M., Capanna, M.C., Witcher, R.E., Wouda N., Attema, P.A.J., Bronkhorst, A.J., et al. in prep. Merging Disparate Archaeological Survey Datasets: The Construction of the Roman Hinterland Project Database.

Ward-Perkins, B. 2005. The Fall of Rome and the End of Civilization. Oxford: Oxford University Press.

Willet, R. 2014. Experiments with Diachronic Data Distribution Methods Applied to Eastern Sigillata $\mathrm{A}$ in the Eastern Mediterranean. HEROM. Journal on Hellenistic and Roman Material Culture, 3: 39-69.

Witcher, R.E. 2005. The Extended Metropolis: Urbs, Suburbium and Population. Journal of Roman Archaeology, 18: 120-38.

Witcher, R.E. 2008. (Re)Surveying Mediterranean Rural Landscapes: GIS and Legacy Survey Data. Internet Archaeology, 24. https://doi.org/10.11141/ia.24.2

Woolf, G. 1992. Imperialism, Empire and the Integration of the Roman Economy. World Archaeology, 23: 283-93.

\section{Biographical Notes}

Peter Attema is professor of Classical and Mediterranean archaeology at the University of Groningen, specializing in 
settlement and landscape archaeology. He directs the Pontine Region Project.

Address: Groningen Institute of Archaeology, Poststraat 6, 9712 ER Groningen, The Netherlands. [Email: p.a.j.attema@ rug.nl]. ORCID: https://orcid.org/00000003-1360-5757.

Paolo Carafa is professor of Classical archaeology at the University of Rome, La Sapienza. His research focuses on urban and rural landscape archaeology in preRoman and Roman Italy. He directs the Roman Suburbium Project.

Address: Dipartimento di Scienze dell'Antichità, Sapienza Università di Roma, P. le A. Moro 5, 00185, Rome, Italy. [Email: paolo.carafa@uniroma1.it]. ORCID: https:// orcid.org/0000-0002-2981-9744.

Willem Jongman was a reader in economic history in the University of Groningen until his recent retirement. His work focuses on long-term trends in the Roman economy, often using a combination of archaeological data and economic analysis.

Address: Breedeborg 17, 9722 WK Groningen, The Netherlands. [Email: w.m.jongman@rug.nl]. ORCID: https:// orcid.org/0000-0003-3942-1892.

Christopher Smith is professor of ancient history at the University of St Andrews. He was Director of the British School at Rome from 2009 to 2017.

Address: School of Classics, University of St Andrews, Swallowgate, The Scores, St Andrews, Scotland, UK. [Email: cjs6@standrews.ac.uk]. ORCID: https://orcid.org/ 0000-0002-6049-5514.
Remco Bronkhorst is a $\mathrm{PhD}$ student at the Universities of Groningen and $\mathrm{St}$ Andrews. His project concerns the economy of pre-Roman central Italy with a focus on Crustumerium and Satricum.

Address: Groningen Institute of Archaeology, Poststraat 6, 9712 ER Groningen, The Netherlands. [Email: a.j. bronkhorst@rug.nl]. ORCID: https:// orcid.org/0000-0002-3389-5045.

Maria Cristina Capanna is a post-doctoral researcher in Classical archaeology at the University of Rome, La Sapienza. Expert in ICT applications in archaeology, her research focuses on urban and rural ancient landscapes, in pre-Roman and Roman Italy.

Address: Dipartimento di Scienze dell'Antichità, Sapienza Università di Roma, P.le A. Moro 5, 00185, Rome, Italy. [Email: mariacristina.capanna@ uniroma1.it]. ORCID: https://orcid.org/ 0000-0002-6849-1550.

Tymon de Haas is assistant professor at the Faculty of Archaeology at Leiden University. His research concerns the landscape, environment, and economy of the Italian peninsula with a focus on Roman central Italy. He is co-director of the Pontine Region Project.

Address: Leiden University, Faculty of Archaeology, Einsteinweg 2, 2333 CC Leiden, The Netherlands. [Email: t.c.a.de. haas@arch.leidenuniv.nl]. ORCID: https://orcid.org/0000-0002-3138-7012.

Martijn van Leusen is associate professor of landscape archaeology at the University of Groningen. His research interests include applications of geographical 
information systems, spatial modelling, the protohistory of central and southern Italy, and archaeological methodology.

Address: Groningen Institute of Archaeology, Poststraat 6, 9712 ER Groningen, The Netherlands. [Email: p. m.van.leusen@rug.nl]. ORCID: https:// orcid.org/0000-0002-4778-9534.

Gijs Tol is a senior lecturer in Roman archaeology at the University of Melbourne and specializes in the archaeology of the Roman countryside with a particular emphasis on rural settlement organization and the study of local and regional economic networks.

Address: School of Historical and Philosophical Studies, The University of Melbourne, Office 671, Arts West (Building 148), Parkville, 3010 VIC, Melbourne, Australia. [Email: gijs.tol@ unimelb.edu.au]. ORCID: https://orcid. org/0000-0003-0743-5173.
Robert Witcher is associate professor of archaeology at Durham University. His research focuses on landscape archaeology and the archaeology of the Roman period.

Address: Department of Archaeology, Durham University, South Road, Durham, DH1 3LE, UK. [Email: r.e. witcher@durham.ac.uk]. ORCID: https:// orcid.org/0000-0001-6918-4897.

Niels Wouda is a $\mathrm{PhD}$ researcher in operations research at the Faculty of Economics and Business at the University of Groningen. He is responsible for the technical implementation of the RHPdb.

Address: Faculty of Economics and Business, University of Groningen, Nettelbosje 2, 9747 AE Groningen, The Netherlands. [Email: n.a.wouda@rug.nl]. ORCID: https://orcid.org/0000-00032463-0309.

\section{Le project de l'arrière-pays romain: intégration des données provenant de prospections de terrain autour de Rome et au-delà}

Cet article présente le contexte et les perspectives d'une nouvelle initiative de recherche archéologique de terrain et d'intégration de bases de données. Le "Roman Hinterland Project " combine les données du " Tiber Valley Project", du "Roman Suburbium Project " et du "Pontine Region Project " dans une seule base de données, que nous considérons comme l'un des référentiels de données le plus complet pour l'arrière-pays d'une grande métropole sur près de 2000 ans d'histoire. Cet article expose la logique de la combinaison de ces bases de données dans le contexte de l'étude du paysage romain, et illustre avec plusieurs analyses sa capacité de contribuer aux grands débats concernant l'économie romaine, la démographie et la comprébension sur la longue durée de la condition humaine dans un monde globalisé. Translation by the authors.

Mots-clés: archéologie de l'habitat, intégration de données, prospection régionale comparative, rapports urbains-ruraux, démographie rurale, économie rurale, suburbium de Rome 


\section{Das römische Hinterland Projekt: die Integrierung der Daten aus Felduntersuchungen in der Umgebung von Rom und weiter hinaus}

Dieser Artikel beschreibt den Hintergrund und die Aussichten für eine neue Initiative in der archäologischen Felduntersuchung und Datenbankintegration. Das „Roman Hinterland Project“ kombiniert Daten aus dem "Tiber Valley-Project", dem „Roman Suburbium Project" und dem „Pontine Region Project" in einer einzigen Datenbank, die unserer Ansicht nach eines der vollständigsten Datenbestände für das Hinterland einer großen Metropole in fast 2000 Jahren Geschichte darstellt. Die Verfasser betrachten die Logik der Kombination dieser Datenbanken im Kontext der Untersuchung der römischen Landschaft und zeigen mit mehreren Analysen das Potenzial für wichtige Debatten in der römischen Wirtschaft, Demografie und das Verständnis der longue durée des menschlichen Zustands in einer globalisierenden Welt. Translation by the authors.

Stichworte: Siedlungsarchäologie, Integration von Daten, vergleichende regionale Felduntersuchungen, Beziehungen zwischen Stadt und Land, ländliche Demografie, ländliche Wirtschaft, suburbium von Rom 